\title{
Regulation of GNRH production by estrogen and bone morphogenetic proteins in GT1-7 hypothalamic cells
}

\author{
Hiroyuki Otani, Fumio Otsuka, Masaya Takeda, Tomoyuki Mukai, Tomohiro Terasaka, Tomoko Miyoshi, \\ Kenichi Inagaki, Jiro Suzuki, Toshio Ogura, Mark A Lawson ${ }^{\mathbf{1}}$ and Hirofumi Makino \\ Department of Medicine and Clinical Science, Okayama University Graduate School of Medicine, Dentistry and Pharmaceutical Sciences, 2-5-1 Shikata-cho, \\ Kitaku, Okayama City 700-8558, Japan \\ ${ }^{1}$ Department of Reproductive Medicine, University of California, San Diego, 9500 Gilman Drive, La Jolla, California 92093, USA \\ (Correspondence should be addressed to F Otsuka; Email: fumiotsu@md.okayama-u.ac.jp)
}

\begin{abstract}
Recent studies have shown that bone morphogenetic proteins (BMPs) are important regulators in the pituitary-gonadal endocrine axis. We here investigated the effects of BMPs on GNRH production controlled by estrogen using murine GT1-7 hypothalamic neuron cells. GT1-7 cells expressed estrogen receptor $\alpha(\mathrm{ER} \alpha$; ESR 1 as listed in MGI Database), ER $\beta$ (ESR2 as listed in MGI Database), BMP receptors, SMADs, and a binding protein follistatin. Treatment with BMP2 and BMP4 had no effect on Gnrh mRNA expression; however, BMP6 and BMP7 significantly increased Gnrh mRNA expression as well as GnRH production by GT1-7 cells. Notably, the reduction of Gnrh expression caused by estradiol $\left(\mathrm{E}_{2}\right)$ was restored by cotreatment with BMP2 and BMP4, whereas it was not affected by BMP6 or BMP7. $\mathrm{E}_{2}$ activated extracellular signal-regulated kinase (ERK) $1 / 2$ and stress-activated protein kinase/c-Jun $\mathrm{NH}_{2}$-terminal kinase (SAPK/JNK) signaling but did not activate p38-mitogenactivated protein kinase (MAPK) signaling in GT1-7 cells. Inhibition of ERK1/ERK2 reversed the inhibitory effect of

estrogen on Gnrh expression, whereas SAPK/JNK inhibition did not affect the $E_{2}$ actions. Expression levels of $E r \alpha$ and $E r \beta$ were reduced by BMP2 and BMP4, but were increased by BMP6 and BMP7. Treatment with an ER antagonist inhibited the $\mathrm{E}_{2}$ effects on Gnrh suppression including reduction of $\mathrm{E}_{2}$-induced $\mathrm{ERK}$ phosphorylation, suggesting the involvement of genomic ER actions in Gnrh suppression. BMP2 and BMP4 also suppressed estrogen-induced phosphorylation of ERK1/ERK2 and SAPK/JNK signaling, suggesting that BMP2 and BMP4 downregulate estrogen effects by attenuating ER-MAPK signaling. Considering that BMP6 and BMP7 increased the expression of $\alpha 1 \mathrm{E}$-subunit of R-type calcium channel (Cacna1e), which is critical for GNRH secretion, it is possible that BMP6 and BMP7 directly stimulate GNRH release by GT1-7 cells. Collectively, a newly uncovered interaction of BMPs and ER may be involved in controlling hypothalamic GNRH production and secretion via an autocrine/paracrine mechanism.

Journal of Endocrinology (2009) 203, 87-97
\end{abstract}

\section{Introduction}

Reproduction in mammals is controlled by the coordination between episodic release of GNRH and GNRH-dependent secretion of pituitary gonadotropins. GNRH is a highly conserved decapeptide, which is secreted by a scattered group of cells located in the hypothalamus. The pattern of GNRH secretion is regulated by the intrinsic oscillatory activity of GNRH neurons and the integration of presynaptic inputs of various neurotransmitters. GNRH synthesis and release are tightly regulated by gonadal steroids, which maintain control through a negative feedback system (Petersen et al. 2003). In females, estrogens act directly or indirectly on GNRH neuronal network to modulate the final output of GNRH into the median eminence (Herbison 1998, Herbison \& Pape 2001). Estrogen receptors (ER) belong to the superfamily of nuclear receptors and are classified as class I ligand-activated transcription factors. There are two identified subtypes of $\operatorname{ER} \alpha$ and $\operatorname{ER} \beta$ (ESR1 and ESR2 as listed in MGI Database), which are encoded by separate genes and differ in structure, function, and anatomical distribution.

The characterization of specific estrogen effects and identification of ER-dependent signaling pathways have been difficult in GNRH neurons. In this respect, immortalized GNRH-producing GT1-7 cells have proven to be a valuable tool to study the biology of GNRH neurons (Liposits et al. 1991, Wetsel et al. 1991). Although earlier studies indicated that GNRH neurons generally lack steroid hormone receptors, recent studies have provided evidence that GT1-7 cells express functional ER, suggesting that estrogen regulates GNRH production and secretion directly in GNRH neuron in the reproductive system composed of hypothalamo-pituitary-ovarian (HPO) axis. 
Bone morphogenetic proteins (BMPs), which belong to the transforming growth factor- $\beta$ (TGF- $\beta$ or TGFB1 as listed in MGI Database) superfamily, were originally identified as the active components in bone extracts capable of inducing bone formation at ectopic sites. Recent studies have shown that BMPs are crucial molecules in normal folliculogenesis by regulating gonadotropin-induced steroidogenesis and mitosis in ovarian granulosa cells (Otsuka et al. 2000, Otsuka \& Shimasaki 2002a, Shimasaki et al. 2004). The major regulatory process by BMPs in ovarian steroidogenesis is the control of FSH receptor signaling (Otsuka et al. 2001a,b), leading to normal follicular development in the ovary with prevention of immature ovulation. Furthermore, the pituitary BMP system acts as a regulator not only for pituitary differentiation but also for the transformation of differentiated pituitary cells (Otsuka \& Shimasaki 2002b, Takeda et al. 2003, 2007, Miyoshi et al. 2008). It is of note that BMPs activate FSH production by the pituitary gonadotrope (Huang et al. 2001, Otsuka \& Shimasaki 2002b, Nicol et al. 2008). Functional communication between the ovary and central nervous system ensures that the neural signal for ovulation occurs when ovarian follicles are fully matured. Hence, BMPs play crucial roles in female reproduction not only by regulating ovarian steroidogenesis and mitogenesis but also by activating pituitary gonadotropin secretion in an autocrine/paracrine manner.

However, the effects of BMPs on hypothalamic GNRH production and secretion have yet to be elucidated. In the present study, we here investigated the effects of BMPs on GNRH production controlled by estrogen using murine GT1-7 hypothalamic neuron cells. A novel interaction between BMPs and ER, which is involved in controlling hypothalamic GNRH production and secretion, was here uncovered.

\section{Materials and Methods}

\section{Reagents and supplies}

DMEM, dimethyl sulfoxide, penicillin-streptomycin solution, $17 \beta$-estradiol $\left(\mathrm{E}_{2}\right)$, BSA-conjugated $\mathrm{E}_{2}\left(\mathrm{E}_{2}-\mathrm{BSA}\right)$, ICI 182780 (also called fulvestrant), and recombinant human activin A were purchased from Sigma-Aldrich Co. Ltd. Recombinant human BMP-2, -4, -6, and -7 were purchased from R\&D Systems Inc. (Minneapolis, MN, USA), recombinant human platelet-derived growth factor (PDGF)-BB was purchased from PeproTech (London, UK), and U0126 and SB203580 were purchased from Promega Corp. SP600125 was purchased from Biomol Lab. Inc (Plymouth Meeting, PA, USA). Mouse ovary total RNA was purchased from Ambion (Austin, TX, USA). For the experiments using $E_{2}$-BSA, the preparation of $E_{2}$-BSA free of estradiol was performed as previously reported (Taguchi et al. 2004, Takahashi et al. 2008): $4 \mathrm{ml} \mathrm{E}$-BSA (1.25 mM in estrogen dissolved in $50 \mathrm{mM}$ Tris- $\mathrm{HCl}(\mathrm{pH} \mathrm{8.5))} \mathrm{was}$ added to a Amicon Ultra centrifugal filter unit with a MW cut off of 5000 (Millipore, Bedford, MA, USA) and centrifuged at $4000 \mathrm{~g}$ until $50 \mathrm{ml}$ retentate remained. The retentate was washed with Tris buffer, and final volume was adjusted to $5 \mathrm{ml}(1 \mathrm{mM})$.

\section{GT1-7 cell culture}

GT1-7 cells were kindly provided by Dr Pamela L Mellon, University of California, San Diego, CA, USA. GT1-7 cells were maintained in DMEM supplemented with 10\% FCS, penicillin, and streptomycin (Sigma-Aldrich Corp.) at $37{ }^{\circ} \mathrm{C}$ in $5 \% \mathrm{CO}_{2}$ humidified atmosphere. The culture medium was changed twice a week, and cultures were passaged at $\sim 80 \%$ confluence. Changes in cell morphology and growing conditions were carefully monitored under an inverted microscope.

\section{RNA extraction, RT-PCR, and quantitative real-time PCR analysis}

GT1-7 cells $\left(2 \times 10^{5}\right.$ viable cells $\left./ \mathrm{ml}\right)$ were precultured in serum-free DMEM, and cells were treated with indicated concentrations of BMPs in combination with $\mathrm{E}_{2}$ and various chemical inhibitors including U0126, SB203580, SP600125, and ICI 182780 . After 24-h culture, the medium was removed, and total cellular RNAs were extracted using TRIzol (Invitrogen Corp.), subsequently quantified by measuring absorbance at $260 \mathrm{~nm}$ and stored at $-80{ }^{\circ} \mathrm{C}$ until assay. The expression of BMP receptors (Bmprs), Smads, Ers, and Gnrh was detected by RT-PCR analysis. The extracted RNA $(1 \mu \mathrm{g})$ was subjected to a RT reaction using First-Strand cDNA Synthesis System (Invitrogen Corp.) with random hexamer $(2 \mathrm{ng} / \mu \mathrm{l})$, reverse transcriptase (200 U), and dNTP $(0.5 \mathrm{mM})$ at $42^{\circ} \mathrm{C}$ for $50 \mathrm{~min}, 70{ }^{\circ} \mathrm{C}$ for $10 \mathrm{~min}$. Subsequently, hot-start PCR was performed using $\mathrm{MgCl}_{2}$ $(1.5 \mathrm{mM})$, dNTP $(0.2 \mathrm{mM})$, and Taq DNA polymerase (2.5 U) (Invitrogen Corp). Oligonucleotides used for PCR were custom ordered from Invitrogen Corp. PCR primer pairs were selected from different exons of the corresponding genes to discriminate PCR products that might arise from possible chromosome DNA contaminants. The primer pairs for mouse BMP receptors, Smads, and a housekeeping gene, ribosomal protein-L19 ( $R$ pl19), were selected as reported (Kano et al. 2005, Takeda et al. 2007, Miyoshi et al. 2008). For Ers, Gnrh, and calcium channel $\alpha 1 \mathrm{E}$-subunit (Cacna1e) genes, the following sequences were used: Er $\alpha, 1523-1543$ and 1737-1757 from GenBank accession number NM_007956; $\operatorname{Er} \beta, \quad 701-721$ and 1004-1024 from NM_010157; Gnrh, 90-110 and 316-336 from BC116897; and calcium channel $\alpha 1 \mathrm{E}, 3181-3201$ and 3403-3423 from NM_009782. The aliquots of PCR products were electrophoresed on $1.5 \%$ agarose gels and visualized after ethidium bromide staining. For the quantification of Gnrh, Er $\alpha$, Er $\beta$, Cacna1e, and Rpl19 mRNA levels, real-time PCR was performed using LightCycler FastStart DNA master 
SYBR Green I system (Roche Diagnostic Co.) under each optimized condition of annealing at $59-63{ }^{\circ} \mathrm{C}$ with $4 \mathrm{mM}$ $\mathrm{MgCl}_{2}$, following the manufacturer's protocol. Accumulated levels of fluorescence for each product were analyzed by the second derivative method after the melting curve analysis (Roche Diagnostic Co.), and then, following the assay validation by calculating each amplification efficiency (Rpl19, 98.5\%; Gnrh, 89\%; Er $\alpha, 88 \% ; E r \beta, 92 \%$; and calcium channel $\alpha 1 \mathrm{E}, 105 \%)$, the expression levels of target genes were quantified based on standard curve analysis for each product and normalized by Rpl19 level in each target.

\section{Measurement of GNRH production}

To assess the effects of BMPs on GNRH protein synthesis, GT1-7 cells $\left(2 \times 10^{5}\right.$ viable cells $\left./ \mathrm{ml}\right)$ were cultured in 96-well plates with DMEM containing $10 \%$ FCS for $24 \mathrm{~h}$. The medium was then changed to serum-free DMEM and subsequently treated with the indicated concentrations of BMPs and $E_{2}$. After 24-h culture, the supernatant of the culture media was collected and stored at $-80{ }^{\circ} \mathrm{C}$ until assay. GNRH concentration $(\mathrm{pg} / \mathrm{ml})$ in the conditioned medium was determined by RIA as previously reported (Chappell et al. 2003). Briefly, $0 \cdot 1 \mathrm{ml}$ aliquots of each sample were incubated for $48 \mathrm{~h}$ with GNRH antibody EL-14 at $4{ }^{\circ} \mathrm{C}$, after which time 10000 c.p.m. sample of radio-iodinated GNRH (Amersham Pharmacia) was added. Following ethanol precipitation of the bound fractions after 48-h incubation, radioactivity was detected by a gamma scintillation counter (Micromedic, Huntsville, AL, USA), and the standard curve analysis was performed at each assay. The inter- and intra-assay variability are $8 \cdot 7$ and $7 \cdot 7 \%$ respectively in the current RIA.

\section{Thymidine incorporation assay}

GT1-7 cells $\left(1 \times 10^{5}\right.$ viable cells $\left./ \mathrm{ml}\right)$ were precultured in 12-well plates with DMEM containing 10\% FCS for $24 \mathrm{~h}$. After preculture medium was replaced with fresh serum-free medium and indicated concentrations of $E_{2}, B M P s$ and PDGF-BB were added to the culture medium. After 24-h culture, $0.5 \mu \mathrm{Ci} / \mathrm{ml}\left[\right.$ meth $\left.y l-{ }^{3} \mathrm{H}\right]$ thymidine (Amersham Pharmacia) was added and incubated for $3 \mathrm{~h}$ at $37^{\circ} \mathrm{C}$. The incorporated thymidine was detected as previously reported (Takahashi et al. 2008). Cells were then washed with PBS, incubated with 10\% ice-cold trichloroacetic acid for $60 \mathrm{~min}$ at $4^{\circ} \mathrm{C}$, and solubilized in $0.5 \mathrm{M} \mathrm{NaOH}$, and radioactivity was determined with a liquid scintillation counter (TRI-CARB 2300TR, Packard Co., Meriden, CT, USA).

\section{Western immunoblot analysis}

GT1-7 cells $\left(1 \times 10^{5}\right.$ viable cells $\left./ \mathrm{ml}\right)$ were precultured in 12-well plates in serum-free DMEM. After 24-h preculture, BMPs and activin A $(100 \mathrm{ng} / \mathrm{ml})$ were added to the culture medium either alone or in combination with $\mathrm{E}_{2}(100 \mathrm{nM})$. After acute $(10-60 \mathrm{~min})$ or chronic $(24 \mathrm{~h})$ stimulations with indicated concentrations of BMPs in combination with $\mathrm{E}_{2}$ and various chemical inhibitors including U0126, SB203580, SP600125, and ICI 182780 , cells were solubilized in $100 \mu$ RIPA lysis buffer (Upstate Biotechnology, Lake Placid, NY, USA) containing $1 \mathrm{mM}$ $\mathrm{Na}_{3} \mathrm{VO}_{4}, 1 \mathrm{mM} \mathrm{NaF}, 2 \%$ SDS, and 4\% $\beta$-mercaptoethanol.
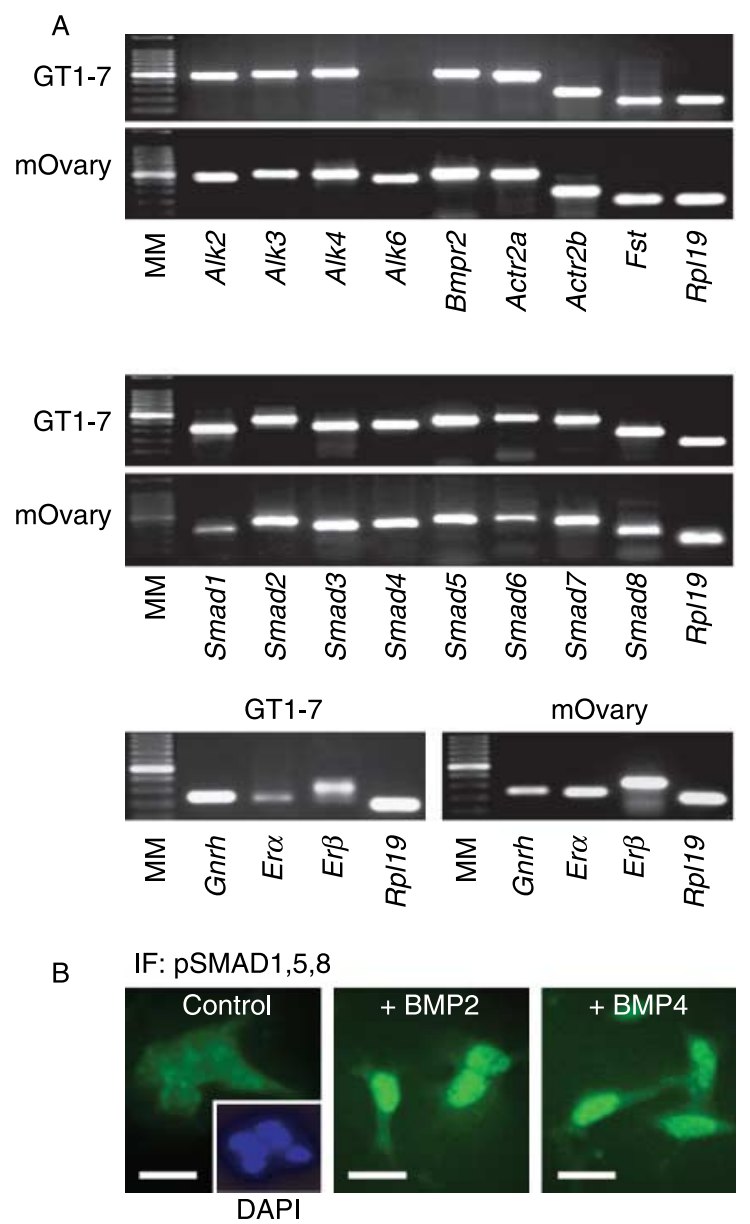

Figure 1 Expression of BMP system and estrogen receptor (ER) in GT1-7 cells. (A) Total cellular RNAs were extracted from GT1-7 cells and quantified by measuring the absorbance of the sample at $260 \mathrm{~nm}$. The expression of mRNAs encoding Alk-2, -3, -4, -6, Bmpr2, Actr2a, Actr2b, Fst, Smad1-8, Gnrh, Era, Erß, and a housekeeping gene Rp/19 was examined by RT-PCR analysis in GT1-7 cells compared with a control sample extracted from mouse ovarian tissues. Aliquots of PCR products were electrophoresed on $1 \cdot 5 \%$ agarose gel, visualized by ethidium bromide staining, and shown as representative of those obtained from three independent experiments. MM indicates molecular weight marker. (B) GT1-7 cells were precultured for $24 \mathrm{~h}$ and stimulated with BMP-2 and -4 $(100 \mathrm{ng} / \mathrm{ml})$ for $1 \mathrm{~h}$. Immunofluorescence (IF) studies were performed using anti-phospho-SMAD1, 5, 8 (pSMAD1, 5, 8) antibody on BMP-treated cells. DAPI indicates counterstaining with $4^{\prime}, 6^{\prime}$-diaminodino-2-phenylindole. Bars indicate $20 \mu \mathrm{m}$ in size. 


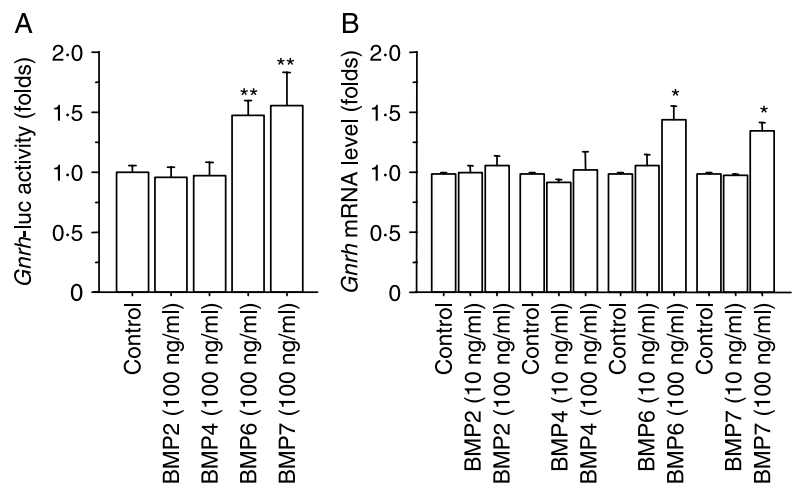

Figure 2 Effects of BMPs on Gnrh transcription and Gnrh mRNA expression in GT1-7 cells. (A) GT1-7 cells $\left(1 \times 10^{5}\right.$ cells $\left./ \mathrm{ml}\right)$ were transiently transfected with Gnrh-luc reporter plasmid (500 ng) and pCMV- $\beta$-gal. After 24-h treatment with BMP-2, -4, -6, and -7 $(100 \mathrm{ng} / \mathrm{ml})$, cells were lysed and the luciferase activity was measured. The data were analyzed as the ratio of luciferase to $\beta$-galactosidase ( $\beta$-gal) activity. Results are shown as mean \pm s.E.M. of data from at least three separate experiments, each performed with triplicate samples. ${ }^{* *} P<0 \cdot 01$ versus control groups. (B) GT1-7 cells $\left(2 \times 10^{5}\right.$ cell $\left.\mathrm{s} / \mathrm{ml}\right)$ were treated with BMP-2, $-4,-6$, and -7 $(10$ and $100 \mathrm{ng} / \mathrm{ml})$ in serum-free conditions for $24 \mathrm{~h}$. Total cellular RNA was extracted and Gnrh mRNA levels were examined by quantitative real-time RT-PCR. The expression levels of target genes were standardized by Rp/19 level in each sample. Results are shown as mean \pm S.E.M. of data from at least three separate experiments, each performed with triplicate samples. ${ }^{*} P<0 \cdot 05$ versus control groups.

The cell lysates were then subjected to SDS-PAGE/immunoblotting analysis as previously reported (Inagaki et al. 2006, Otani et al. 2007), using anti-phospho- and anti-totalextracellular signal-regulated kinase (ERK) 1/2 mitogenactivated protein kinase (MAPK) antibody (Cell Signaling Technology, Inc., Beverly, MA, USA), anti-phospho- and anti-total-p38 MAPK antibody (Cell Signaling Technology, Inc.), anti-phospho- and anti-total-stress-activated protein kinase/c-Jun $\mathrm{NH}_{2}$-terminal kinase (SAPK/JNK) MAPK antibody (Cell Signaling Technology, Inc.), anti-phosphoSmad1, 5, 8 (pSmad1, 5, 8) antibody (Cell Signaling Technology, Inc.), anti-Smad5 antibody (Cell Signaling Technology, Inc.), anti-actin antibody (Sigma-Aldrich Co. $\mathrm{Ltd})$, and anti-ER $\alpha$ (MC-20), and anti-ER $\beta$ (H-150) antibodies (Santa Cruz Biotechnology, Inc., Santa Cruz, CA, USA).

\section{Immunofluorescence microscopy}

For the immunofluorescence study, GT1-7 cells were precultured in serum-free DMEM using chamber slides (Nalge Nunc Int, Naperville, IL, USA). Cells at $\sim 50 \%$ confluency were treated with BMP-2 and BMP-4 $(100 \mathrm{ng} / \mathrm{ml})$ for $1 \mathrm{~h}$. Cells were then fixed with $4 \%$ paraformaldehyde in PBS, permeabilized with $0.5 \%$ Triton X-100 in PBS at room temperature, and washed thrice with PBS. The cells were then incubated with
anti-phospho-SMAD1, 5, 8 antibody (Cell signaling Technology, Inc.) for $1 \mathrm{~h}$ and washed thrice with PBS, then with Alexa Fluor 488 anti-rabbit IgG (Invitrogen Corp.) in humidified chamber for $1 \mathrm{~h}$ and washed with PBS, followed by application of the counter medium containing $4^{\prime}, 6^{\prime}$-diaminodino-2-phenylindole (Invitorogen Corp.), and then stained cells were visualized under a fluorescent microscope.

\section{Transient transfection and luciferase assay}

GT1-7 cells $\left(1 \times 10^{5}\right.$ viable cells $\left./ \mathrm{ml}\right)$ were precultured in 12 -well plates in DMEM with 10\% FCS for $24 \mathrm{~h}$. The cells were transiently transfected with $500 \mathrm{ng}$ Gnrh-luc reporter plasmid, which contains 173-bp rat Gnrh promoter region (Nelson et al. 2000), and $50 \mathrm{ng}$ cytomegalovirus- $\beta$-galactosidase plasmid (pCMV- $\beta$-gal) using FuGENE6 (Roche Molecular Biochemicals) for $24 \mathrm{~h}$. The cells were then treated with indicated concentrations of BMPs and $E_{2}$ for $24 \mathrm{~h}$ in serum-free fresh medium. After 24-h culture, the cells were washed with PBS and lysed with Cell Culture Lysis Reagent (Toyobo, Osaka, Japan). Luciferase activity and $\beta$-gal activity of the cell lysate were measured by luminescencerPSN (ATTO, Tokyo, Japan) as previously reported (Miyoshi et al. 2006). The data were shown as the ratio of luciferase to $\beta$-gal activity.
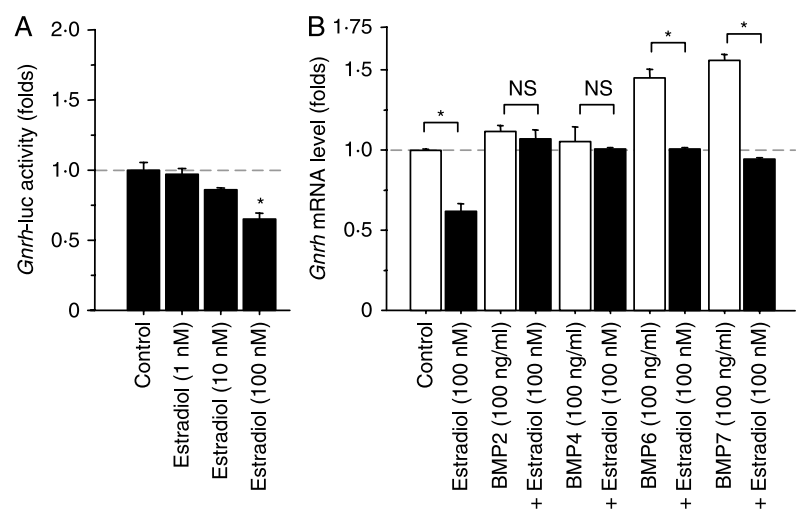

Figure 3 Effects of BMPs and estradiol on Gnrh transcription in GT1-7 cells. (A) GT1-7 cells $\left(1 \times 10^{5}\right.$ cells $\left./ \mathrm{ml}\right)$ were transiently transfected with Gnrh-luc reporter plasmid (500 ng) and pCMV- $\beta$ gal. After 24-h treatment with estradiol (1-100 nM), cells were lysed and the luciferase activity was measured. The data were analyzed as the ratio of luciferase to $\beta$-galactosidase ( $\beta$-gal) activity. Results are shown as mean \pm s.E.M. of data from at least three separate experiments, each performed with triplicate samples. ${ }^{*} P<0 \cdot 05$ versus control groups. (B) Cells $\left(2 \times 10^{5}\right.$ cell $\left./ \mathrm{ml}\right)$ were treated with BMP-2, $-4,-6$, and $-7(100 \mathrm{ng} / \mathrm{ml})$ in the presence or absence of estradiol $(100 \mathrm{nM})$ in serum-free conditions for $24 \mathrm{~h}$. Total cellular RNA was extracted and Gnrh mRNA levels were examined by realtime RT-PCR. The expression levels of target genes were standardized by Rp/19 level in each sample. Results are shown as mean \pm s.E.M. of data from at least three separate experiments, each performed with triplicate samples. ${ }^{*} P<0 \cdot 05$ versus control groups or between the indicated groups; NS, not significant. 

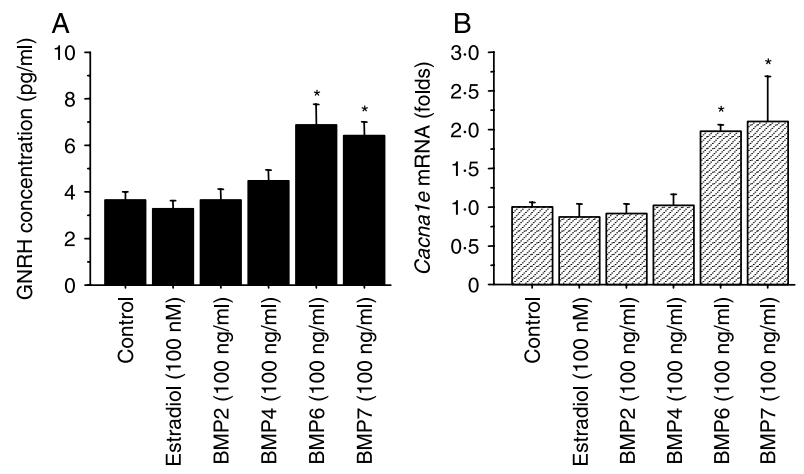

Figure 4 Effects of BMPs on GNRH release by GT1-7 cells. (A) GT1-7 cells $\left(2 \times 10^{5}\right.$ cells $\left./ \mathrm{ml}\right)$ were treated with indicated concentrations of estradiol, BMP-2, $-4,-6$, and -7 in serum-free conditions. After 24-h culture, the culture media was collected, and GNRH concentrations $(\mathrm{pg} / \mathrm{ml})$ were determined by RIA. Results show the mean \pm s.E.M. of data performed with triplicate treatments; $* P<0 \cdot 05$ versus control groups. (B) GT1-7 cells were treated with indicated concentrations of estradiol, BMP-2, $-4,-6$, and -7 in serum-free conditions for $24 \mathrm{~h}$. Total cellular RNA was extracted and mRNA levels of Cacna1e were examined by real-time RT-PCR. The expression levels of target genes were standardized by $R p / 19$ level in each sample. Results are shown as mean \pm s.E.M. of data from at least three separate experiments, each performed with triplicate samples. ${ }^{*} P<0 \cdot 05$ versus control groups.

\section{Statistical analysis}

All results are shown as mean \pm s.E.M. of data from at least three separate experiments, each performed with triplicate samples. Differences between groups were analyzed for statistical significance using ANOVA with Fisher's protected least significant difference (PLSD) test (StatView 5.0 software, Abacus Concepts, Inc., Berkeley, CA, USA). P values $<0 \cdot 05$ were accepted as statistically significant.

\section{Results}

We first examined mRNA expression of the BMP type I and type II receptors in GT1-7 cells by RT-PCR. As shown in Fig. 1A, the BMP type I receptors including activin receptorlike kinase (Alk2) (also called Actr1a), Alk3 (Bmpr1a), and Alk4 (Actr1b), BMP type II receptors including Bmpr2, Actr2, and $A c t r 2 b$, and a binding protein Fst were clearly expressed in GT1-7 cells. Compared with mouse ovary RNA positive control, the expression of Alk6 (Bmpr1b) was not detected in GT1-7 cells. In addition, mRNA expression of Smad signaling molecules including Smad1, 2, 3, 4, 5, and 8, and inhibitory Smad6 and 7 was also detected (Fig. 1A). The expression of two subtypes of ERs including $\operatorname{Er} \alpha$ and $E r \beta$, and Gnrh mRNA was also confirmed in GT1-7 cells. As shown in Fig. 1B, the immunofluorescence study demonstrated the nuclear localization of phosphorylated SMAD1, 5, 8 molecules in GT1-7 cells stimulated by BMP-2 and -4
$(100 \mathrm{ng} / \mathrm{ml})$, indicating that the BMP receptors and SMADs are functionally active in GT1-7 cells.

To investigate the BMP effects on Gnrh transcription, Gnrh-promoter activity was examined in GT1-7 cells transiently transfected with a Gnrh-luc reporter plasmid containing 173-bp rat Gnrh promoter region (Nelson et al. 2000). In GT1-7 hypothalamic neurons, a neuron-specific enhancer responsible for directing expression of the rat Gnrh gene was identified (Whyte et al. 1995), in which 300-bp upstream region confers enhancer activity to a 173-bp Gnrh promoter specifically in GT1-7 cells. In the present study, in order to simply examine Gnrh promoter activity induced by BMPs, only the key promoter region containing 173-bp rat Gnrh promoter was utilized for this promoter assay. As a result, BMP6 and BMP7 stimulated transcriptional activity of Grrh gene, while BMP2 and BMP4 had no significant effects on Gnrh-promoter activity (Fig. 2A). To further examine the BMP effects on steady-state Gnrh mRNA levels in GT1-7 cells, cells were treated with BMP ligands for $24 \mathrm{~h}$ in serumfree conditions. Treatment with BMP2 and BMP4 (10 and $100 \mathrm{ng} / \mathrm{ml}$ ) had no effect on Gnrh mRNA expression by GT1-7 cells (Fig. 2B). In accordance with the results of Gnrh promoter assay, BMP6 and BMP7 (10 and $100 \mathrm{ng} / \mathrm{ml})$ significantly increased Gnrh mRNA expression (Fig. 2B).

In addition, treatment with $\mathrm{E}_{2}(1-100 \mathrm{nM})$ significantly decreased Gnrh-luc activity (Fig. 3A) and Gnrh mRNA expression levels (Fig. 3B). Notably, $\mathrm{E}_{2}(100 \mathrm{nM})$-induced reduction of Gnrh mRNA was reversed by treatment with BMP2 and BMP4. In contrast, $\mathrm{E}_{2}$-induced Gnrh suppression was not apparently affected by treatment with BMP6 and BMP7 (100 ng/ml; Fig. 3B).

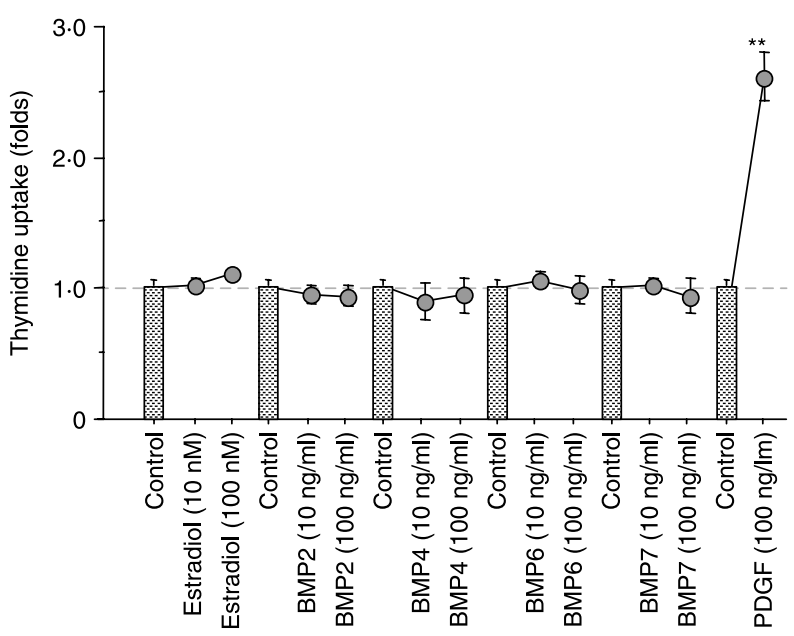

Figure 5 Effects of BMPs and estradiol on GT1-7 cell proliferation. GT1-7 cells $\left(1 \times 10^{5}\right.$ cells $\left./ \mathrm{ml}\right)$ were treated with indicated concentrations of estradiol, BMP-2, $-4,-6,-7$, and PDGF-BB for $24 \mathrm{~h}$ in serum-free condition, and then thymidine uptake assay was performed. Results are shown as mean \pm S.E.M. of data from at least three separate experiments, each performed with triplicate samples. $* * P<0 \cdot 01$ versus control groups. 
The effects of BMPs on GNRH production were evaluated by measuring GNRH concentration in the conditioned medium by RIA (Fig. 4A). In accordance with the results of Gnrh transcription, BMP6 and BMP7 increased GNRH concentration (pg/ml) by GT1-7 cells, while $\mathrm{E}_{2}, \mathrm{BMP} 2$, and BMP4 had no effects on the GNRH levels (Fig. 4A). To investigate the involvement of BMPs in GNRH release by GT1-7 cells, the expression changes in a key calcium channel, $\alpha 1 \mathrm{E}$-subunit were examined (Watanabe et al. 2004). Various stimuli including potassium and acetylcholine have known to induce GNRH secretion through increased influx of intracellular calcium by GT1-7 cells. The $\alpha 1 \mathrm{E}$-subunit of R-type calcium channel was recently shown to be critical for GNRH secretion in GT1-7 cells (Watanabe et al. 2004). BMP6 and BMP7 increased mRNA expression of $\alpha 1 \mathrm{E}-$ subunit of R-type calcium channel, although $\mathrm{E}_{2}, \mathrm{BMP} 2$, and BMP4 had no effects on $\alpha 1 \mathrm{E}$-subunit mRNA (Fig. 4B). In addition, the levels of thymidine incorporation in GT1-7 cells were not increased in response to treatment with $\mathrm{E}_{2}, \mathrm{BMP}-2$, $-4,-6$, and -7 , although GT1-7 cells were responsive to exogenous PDGF-BB (Fig. 5). It is thus possible that BMP6 and BMP7 may directly enhance GNRH release through upregulating a critical calcium channel expression in GT1-7 cells.
Western blots also showed SMAD1, 5, 8 signaling activation by BMP-2, $-4,-6$, and -7 in GT1-7 cells (Fig. 6A). Treatments with BMP-2, -4, -6, and -7 , in particular BMP2 and 4, activated Smad1, 5, 8 phosphorylation in GT1-7 cells (Fig. 6B). The BMP-induced SMAD1, 5,8 activation was not affected in the presence of $E_{2}$ $(100 \mathrm{nM})$. It was of note that treatment with $\mathrm{E}_{2}(100 \mathrm{nM})$ significantly activated MAPK phosphorylation including ERK1/ERK2 and SAPK/JNK but not p38-MAPK signaling (Fig. 6A). BMP-2 and BMP-4 significantly suppressed $\mathrm{E}_{2}$ $(100 \mathrm{nM})$-induced phosphorylation of ERK1/ERK2 and SAPK/JNK signaling, whereas BMP6 and BMP7 did not affect $E_{2}$-induced activation of ERK1/ERK2 and SAPK/ JNK (Fig. 6B). Activin A $(100 \mathrm{ng} / \mathrm{ml})$ induced p38 phosphorylation in the presence or absence of $E_{2}$, while activin $A$ did not affect $E_{2}$-induced ERK1/ERK2 activation.

Since treatment with $\mathrm{E}_{2}$ activated MAPK pathways including ERK1/ERK2 and SAPK/JNK signaling, the functional roles of these pathways in Gnrh transcription were examined. Treatment with $3 \mu \mathrm{M}$ U0126 specifically inhibited basal and $E_{2}$-induced ERK1/ERK2 phosphorylation (Fig. 7A). SP600125 (3 and $10 \mu \mathrm{M})$ inhibited basal and $\mathrm{E}_{2}$-induced SAPK/JNK phosphorylation in GT1-7 cells,
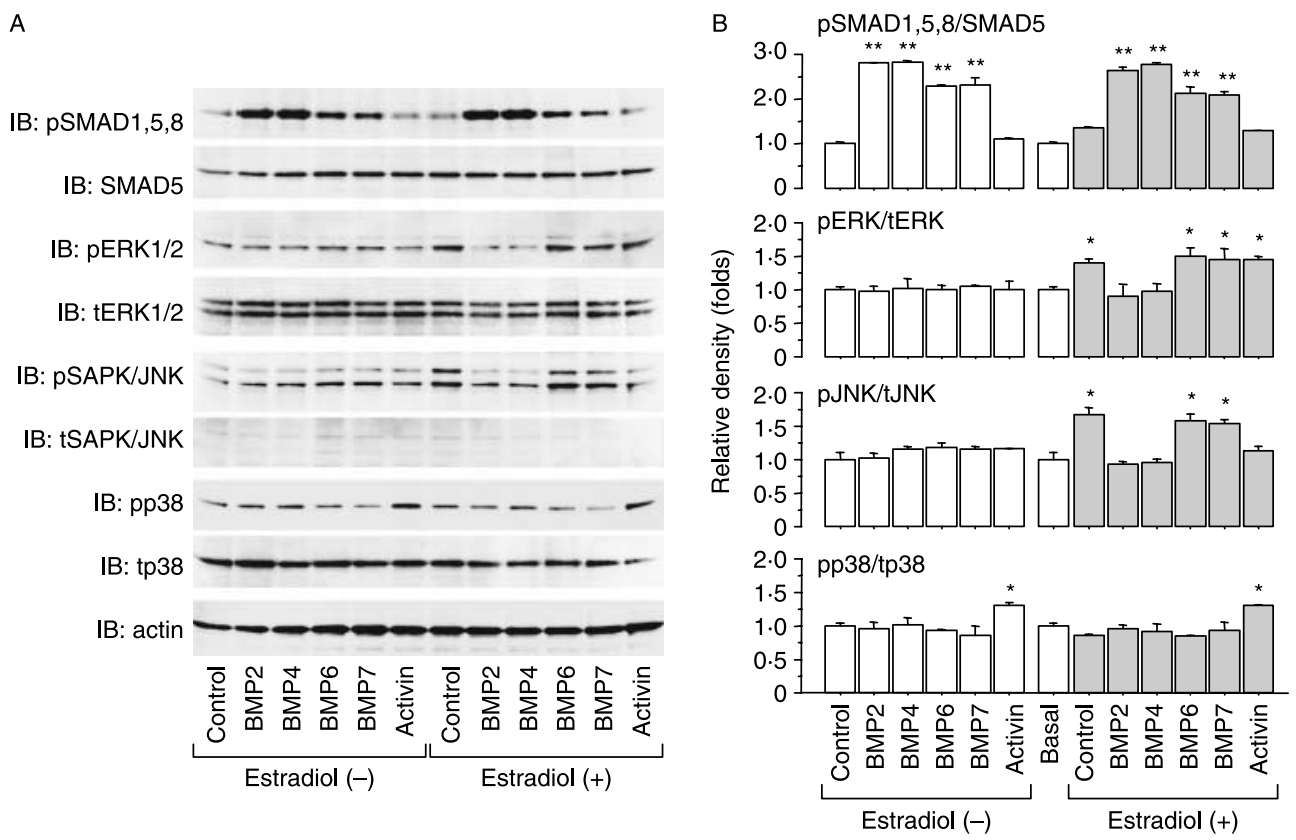

Figure 6 Effects of BMPs and estradiol on SMAD/MAPK signaling in GT1-7 cells. (A) Cells $\left(1 \times 10^{5}\right.$ cells $\left./ \mathrm{ml}\right)$ were precultured for $24 \mathrm{~h}$ in serum-free condition and stimulated with BMP-2, -4, -6, -7, and activin A $(100 \mathrm{ng} / \mathrm{ml})$ in the absence or presence of estradiol $(100 \mathrm{nM})$. After 60-min culture, cells were lysed and subjected to SDS-PAGE/immunoblotting (IB) analysis using anti-phospho-SMAD1, 5, 8 (pSMAD1, 5, 8) and anti-SMAD5, anti-phospho-ERK1/2 (pERK1/2) and anti-total-ERK1/2 (tERK1/2), anti-phospho-SAPK/JNK (pSAPK/JNK) and anti-total-SAPK/JNK (tSAPK/JNK), anti-phospho-p38 (pp38) and anti-total-p38 (tp38), and anti-actin antibodies. The results shown are representative of those obtained from three independent experiments. (B) The relative integrated density of each protein band of Fig. $6 \mathrm{~A}$ was digitized by NIH image J $1.34 \mathrm{~s}$. Results are shown as mean \pm S.E.M. of data from at least three separate experiments, each performed with triplicate samples. ${ }^{*} P<0 \cdot 01$ and ${ }^{*} P<0 \cdot 05$ versus control or basal levels. 


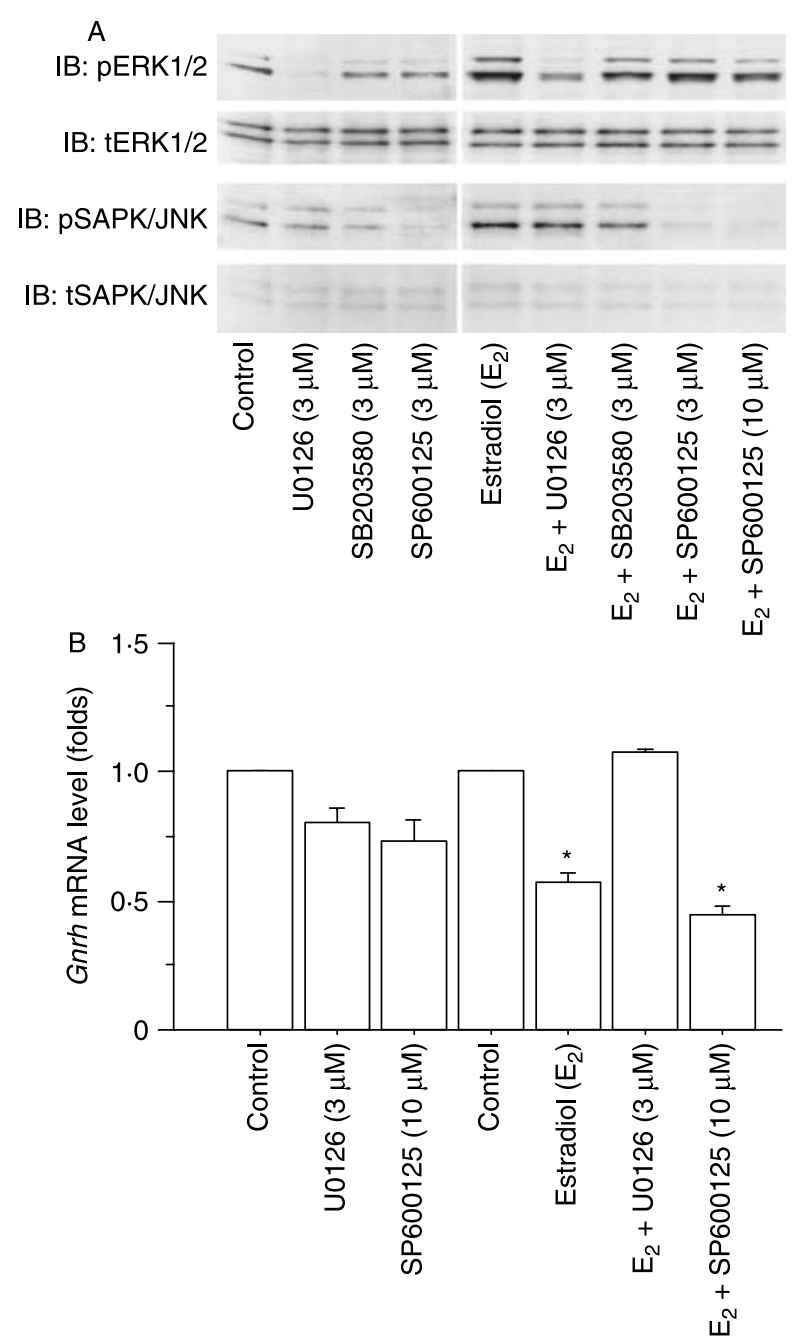

Figure 7 Effects of MAPK inhibition on Gnrh regulation by GT1-7 cells. (A) GT1-7 cells $\left(1 \times 10^{5}\right.$ cells/ml) were precultured for $24 \mathrm{~h}$ and then treated with MAPK inhibitors including U0126, SB203580, and SP600125 (3-10 $\mu \mathrm{M})$ in combination with estradiol $\left(\mathrm{E}_{2} ; 100 \mathrm{nM}\right)$. After 60-min culture, cells were lysed and subjected to SDS-PAGE/immunoblotting (IB) analysis using anti-phosphoERK1/2 (pERK1/2), anti-total-ERK1/2 (tERK1/2), anti-phosphoSAPK/JNK (pSAPK/JNK), and anti-total SAPK/JNK (tSAPK/JNK) antibodies. The results shown are representative of those obtained from three independent experiments. (B) GT1-7 cells $(2 \times$

$10^{5}$ cells $\left./ \mathrm{ml}\right)$ were treated with $\cup 0126(3 \mu \mathrm{M})$ and SP600125

$(10 \mu \mathrm{M})$ in the absence or presence of estradiol $(100 \mathrm{nM})$ in serumfree conditions for $24 \mathrm{~h}$. Total cellular RNA was extracted and Gnrh mRNA levels were examined by real-time RT-PCR. The expression levels of target genes were standardized by Rp/19 level in each sample. Results are shown as mean \pm s.E.M. of data from at least three separate experiments, each performed with triplicate samples. ${ }^{*} P<0 \cdot 05$ versus control groups.

although SB203580 (3 $\mu \mathrm{M})$ did not affect either ERK1/ ERK2 or SAPK/JNK phosphorylation (Fig. 7A). As shown in Fig. 7B, U0126 $(3 \mu \mathrm{M})$ restored the $E_{2}$-induced suppression of Gnrh expression, although either U0126 or SP600125 alone had no significant effects on Gnrh expression in GT1-7 cells. In contrast, SP600125 (10 $\mu \mathrm{M})$ failed to reverse the inhibitory effect of estrogen on Gnrh expression. Thus, the effects of estrogen on Gnrh suppression occur through ERK1/ERK2 activation in GT1-7 cells.

We next investigated whether the $\mathrm{E}_{2}$ actions on MAPK activation and Gnrh suppression are mediated via ER. As shown in Fig. 8A, ERK1/ERK2 phosphorylation induced by $\mathrm{E}_{2}(100 \mathrm{nM})$ was inhibited in the presence of a competitive ER antagonist ICI $182780(30-300 \mathrm{nM})$, although ICI 182780 alone had no effects on ERK phosphorylation. A membrane-impermeable $\mathrm{E}_{2}$-BSA (100 $\left.\mathrm{nM}\right)$ formulation failed to activate ERK1/ERK2 pathway (Fig. 8A). Notably, treatment with ICI 182780 reversed the $E_{2}$-induced suppression of Gnrh mRNA, whereas ICI 182780 (30 nM) or $\mathrm{E}_{2}$-BSA $(100 \mathrm{nM})$ alone did not change the Gnrh expression in GT1-7 cells (Fig. 8B). These suggest that estrogen inhibits Gnrh expression in GT1-7 cells at least in part by activating ERK1/ERK2 pathway via classic ER. Given the finding that BMP2 and BMP4 suppressed estrogeninduced phosphorylation of MAPK signaling, BMP2 and BMP4 may regulate the ER activity leading to GNRH reduction in GT1-7 cells.

To further investigate the involvement of ER in BMPinduced Gnrh regulation, the expression levels of $\operatorname{Er} \alpha$ and $\operatorname{Er} \beta$ mRNA were examined in GT1-7 cells treated with BMPs and $\mathrm{E}_{2}$. BMP2 and BMP4 (10-100 ng/ml) significantly decreased mRNA levels of Er $\alpha$ and $E r \beta$, while BMP6 and BMP7 increased the expression of $\operatorname{Er} \alpha$ and $\operatorname{Er} \beta$ (Fig. 9A and B). $E_{2}(100 \mathrm{nM})$ itself also decreased Er $\alpha$ mRNA levels in GT1-7 cells. In addition, the changes of $\operatorname{ER} \alpha$ and $\operatorname{ER} \beta$ protein levels were examined by western immunoblotting in GT1-7 cell lysates treated with BMP-2, -4, -6, and -7 for $24 \mathrm{~h}$. As shown in Fig. 9C, the expression levels of ER $\alpha$ $(66 \mathrm{kDa})$ and $\operatorname{ER} \beta(56 \mathrm{kDa})$ proteins were decreased by BMP2 and BMP4, while BMP6 and BMP7 in turn increased $\mathrm{ER} \alpha$ and ER $\beta$ protein expression, although the levels of an internal control actin $(42 \mathrm{kDa})$ were unchanged in GT1-7 cells. Thus, BMP2 and BMP4 are likely to downregulate estrogen effects by attenuating estrogen-induced ERK1/ ERK2 activation and by suppressing the expression of ER in GT1-7 cells.

\section{Discussion}

The episodic secretion of pituitary gonadotropin is essential for the maintenance of the mammalian reproductive cycle and normal gonadal function. In the present study, we showed that hyopothalamic GT1-7 neuron cells express functional machinery of the BMP system, and that the BMP system acts to modulate estrogen effects on Gnrh regulation. $\mathrm{E}_{2}$ suppressed GNRH production by activating the MAPK pathway through ER action. In this feedback loop between $\mathrm{E}_{2}$ and GNRH, BMP2 and BMP4 suppress estrogen effects by attenuating estrogen ERK signaling with reduction of ER $\alpha$ and ER $\beta$ expression. In contrast, BMP6 and BMP7 directly 

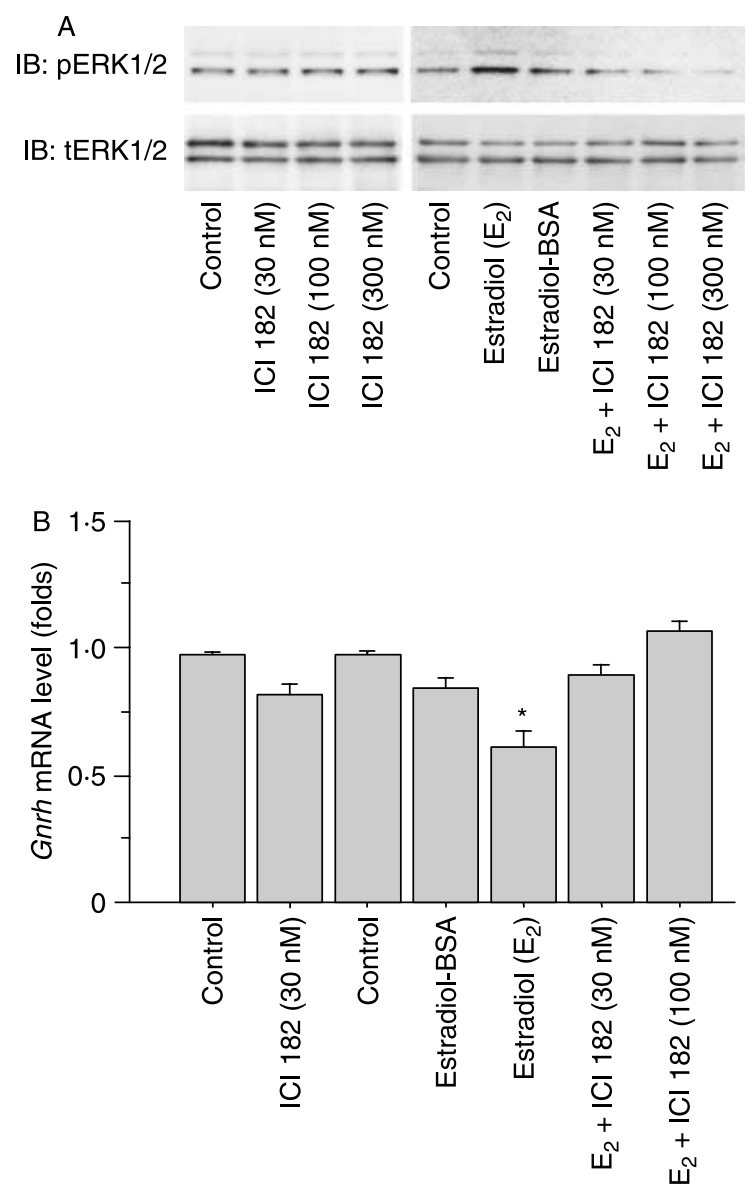

Figure 8 Effects of estrogen receptor (ER) inhibition on Gnrh regulation by GT1-7 cells. (A) GT1-7 cells $\left(1 \times 10^{5}\right.$ cells $\left./ \mathrm{ml}\right)$ were precultured for $24 \mathrm{~h}$ and then treated with ICI 182780 (30$300 \mathrm{nM})$, estradiol $\left(\mathrm{E}_{2} ; 100 \mathrm{nM}\right)$, and estradiol-BSA (100 nM). After 60-min culture, cells were lysed and subjected to SDS-PAGE/ immunoblotting (IB) analysis using anti-phospho-ERK1/2 (pERK1/2) and anti-total-ERK1/2 (tERK1/2) antibodies. The results shown are representative of those obtained from three independent experiments. (B) GT1-7 cells $\left(2 \times 10^{5}\right.$ cells/ml) were treated with ICl $182780(30-100 \mathrm{nM})$, estradiol $\left(\mathrm{E}_{2} ; 100 \mathrm{nM}\right)$, and estradiol-BSA $(100 \mathrm{nM})$ in serum-free conditions for $24 \mathrm{~h}$. Total cellular RNA was extracted and Gnrh mRNA levels were examined by real-time RT-PCR. The expression levels of target genes were standardized by $R p / 19$ level in each sample. Results are shown as mean \pm s.E.M. of data from at least three separate experiments, each performed with triplicate samples. ${ }^{*} P<0 \cdot 05$ versus control groups.

stimulated Gnrh transcription and secretion by GT1-7 cells. This novel interaction of BMPs and ER action is likely involved in controlling hypothalamic GNRH release in an autocrine/paracrine mechanism (Fig. 10).

Estrogen has rapid regulatory effects on membraneassociated and intracellular responses (often referred to as nongenomic actions), in addition to the well-defined genomic actions in the nucleus. In the present study, $\mathrm{E}_{2}$ readily activated MAPK phosphorylation including ERK1/ERK2 and SAPK/JNK but not p38-MAPK signaling, implying the involvement of nongenomic effects of estrogen in GT1-7 cells. BMP2 and BMP4 suppressed the estrogen-induced phosphorylation of ERK1/ERK2 and SAPK/JNK signaling, whereas BMP6 and BMP7 did not affect the $E_{2}$-induced activation of ERK1/ERK2 and SAPK/JNK. Since the inhibition of ERK1/ERK2 restored the $\mathrm{E}_{2}$-induced suppression of Girh expression by GT1-7 cells, the effects of estrogen on Gnrh suppression is likely to occur through ERK1/ERK2 pathway in GT1-7 cells.

These estrogen effects may be distinct from the genomic actions of estrogen and are attributable to its interactions with membrane-bound receptors and other cellular components (Pietras \& Szego 1999, Pietras et al. 2005). Membrane ER has been observed in the hypothalamus and other brain regions, including the cortex, hippocampus, and brain stem. The extent to which GNRH neurons are directly responsive to steroid hormones has been controversial. However, it is now being accepted that hypothalamic cells express both membrane-associated and nuclear receptors, and that they are capable of directly responding to changes in systemic estrogen (Malyala et al. 2005).

In our data, ERK1/ERK2 phosphorylation induced by $E_{2}$ was inhibited in the presence of ICI 182780 , an ER antagonist that inhibits both $\operatorname{ER} \alpha$ and $\operatorname{ER} \beta$ activities. In addition, the effects of membrane-impermeable $\mathrm{E}_{2}$-BSA were much less effective than $E_{2}$ for activating ERK1/ERK2 signaling in GT1-7 cells. ICI 182780 reversed the $\mathrm{E}_{2}$-induced suppression of Gnrh mRNA and $\mathrm{E}_{2}-\mathrm{BSA}$ failed to suppress Gnrh expression in GT1-7 cells. These findings suggest that estrogen inhibits Gnrh expression, at least in part, by activating ERK1/ERK2 pathway via classic ER signaling. Given the finding that BMP2 and BMP4 suppressed estrogen-induced phosphorylation of MAPK signaling, including ERK1/ERK2, BMP2, and BMP4, may directly regulate the ER activity leading to GNRH reduction in GT1-7 cells.

In agreement with our present results, Roy et al. (1999) demonstrated that $\mathrm{E}_{2}$ represses Gnrh gene expression in GT17 cells. This estrogen effect was blocked by ICI 182780 and also mimicked by 2,2-bis-( $p$-hydroxyphenyl)-1,1,1-trichloroethane, a putative $\operatorname{ER} \alpha$ agonist and $\operatorname{ER} \beta$ antagonist (Gaido et al. 1999, Roy et al. 1999), suggesting that ER $\alpha$ may be responsible for the repressive effects of $\mathrm{E}_{2}$ on Gnrh expression. However, a phytoestrogen, coumestrol, also suppressed Gnrh expression, which was in turn blocked by an ER $\beta$ antagonist, $R, R$-tetrahydrochrysene (Bowe et al. 2003). These results also imply that estrogen negatively regulates Gnrh promoter activity via not only ER $\alpha$ but also ER $\beta$ in hypothalamic cells. In the present study, the expression levels of both $E r \alpha$ and $\operatorname{Er} \beta$ were decreased in GT1-7 cells treated with BMP2 and BMP4, which could be linked to the suppression of estrogen-induced MAPK activation. To the contrary, the expression levels of $E r \alpha$ and $\operatorname{Er} \beta$ were increased by BMP 6 and BMP7. This effect may be associated with the upregulation of estrogen-GNRH feedback function following the increase in GNRH production caused by BMP6 and BMP7. 

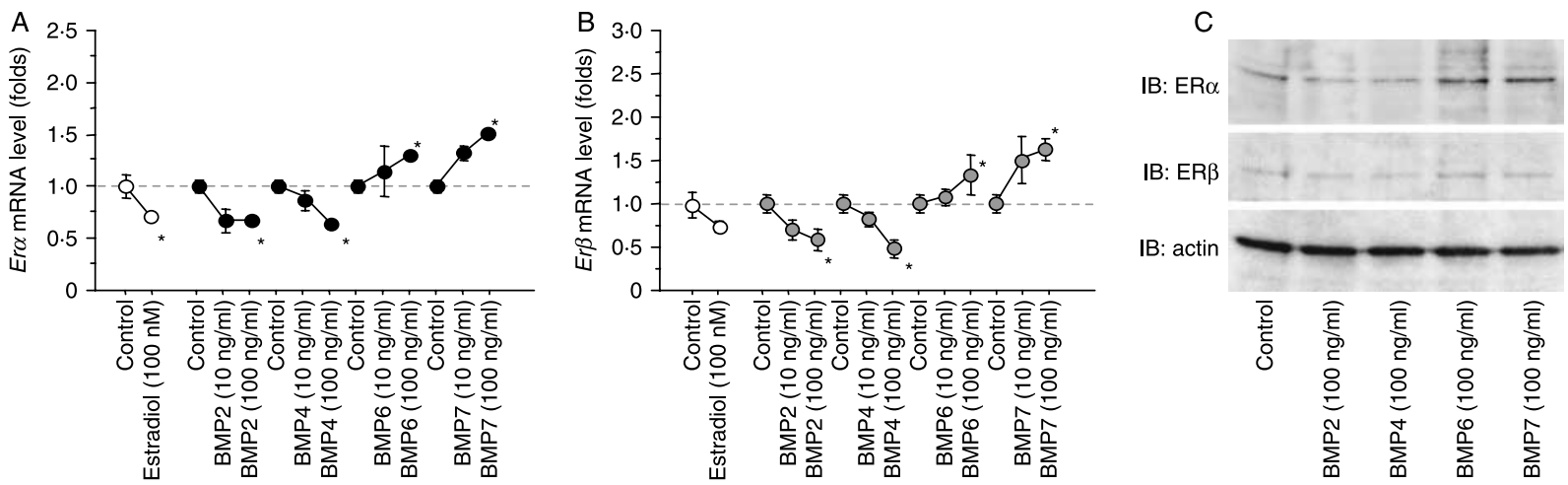

Figure 9 Effects of BMPs and estradiol on estrogen receptor (Er) expression in GT1-7 cells. (A and B) GT1-7 cells were treated with BMP-2, -4, -6, and $-7(10$ and $100 \mathrm{ng} / \mathrm{ml})$ and estradiol $(100 \mathrm{nM})$ in serum-free conditions for $24 \mathrm{~h}$. Total cellular RNA was extracted and $E r \alpha$ and $\operatorname{Er} \beta$ mRNA levels were examined by real-time RT-PCR. The expression levels of target genes were standardized by Rp/19 level in each sample. Results are shown as mean \pm S.E.M. of data from at least three separate experiments, each performed with triplicate samples. ${ }^{*} P<0.05$ versus control groups. (C) Cells $\left(1 \times 10^{5} \mathrm{cell} \mathrm{s} / \mathrm{ml}\right)$ were treated with BMP-2, $-4,-6$, and $-7(100 \mathrm{ng} / \mathrm{ml})$ in serum-free condition. After 24-h culture, cells were lysed and subjected to SDS-PAGE/immunoblotting (IB) analysis using anti-ER $\alpha$, anti-ER $\beta$, and anti-actin antibodies. The results shown are representative of those obtained from three independent experiments.

The mechanism whereby estrogen regulates GNRH secretion may be partly due to an indirect effect on the neighboring neurons, wherein estrogen acts in part to stimulate the GNRH and LH surge by turning off inhibitory neurons and turning on excitatory neurons. The principal determinants of GNRH neuronal activity include gonadal steroids, various neuropeptides, and neurotransmitters. In this regard, work from several laboratories has shown that hypothalamic astrocytes release the factors that can stimulate GNRH release (Gallo \& Russell 1995, Melcangi et al. 1995a, Avola et al. 2000, Buchanan et al. 2000, Ojeda et al. 2000, Dhandapani et al. 2003). Conditioned media collected from purified hypothalamic astrocytes markedly stimulated GNRH release from GT1-7 neurons, an immortalized GNRH neuronal cell line (Buchanan et al. 2000). A similar GNRH stimulatory effect has been reported with conditioned media from cerebral cortical astrocytes (Melcangi et al. 1995b). In our current study, $\mathrm{E}_{2}$ suppressed Gnrh transcription, whereas GNRH protein concentration was not significantly changed in the culture medium. The suppression of Gnrh mRNA was observed in GT1-7 cells in our data and by others (Roy et al. 1999). Regarding GNRH secretion, Navarro et al. (2003) reported that GNRH release was not affected by picomolar of estrogen in static culture of GT1-7 cells and hypothalamic cells, which was rather up-regulated in the presence of cyclic treatment with progesterone. Given that $\mathrm{E}_{2}$ did not affect the expression of a key calcium channel for GNRH secretion in GT1-7 cells, $\mathrm{E}_{2}$ may not directly regulate the GNRH release at least for a certain culture period regardless of the reduction of Gnrh transcription. The discrepancy between transcriptional regulation and secretory process of GNRH needs to be elucidated in a future study.

It has been reported that TGF- $\beta 1$ as a neuroregulatory factor secreted by astrocytes can modulate GNRH secretion
(Melcangi et al. 1995b, Galbiati et al. 1996, Buchanan et al. 2000, Zwain et al. 2002). Additionally, Ojeda et al. have provided evidence in support of a neuroregulatory role for astrocyte-derived TGF- $\alpha$ (Ma et al. 1992, 1997, Ojeda et al. 2000). Furthermore, neuroactive steroid metabolites such as $3 \alpha$-hydroxy- $5 \alpha$-pregnan-20-one $(3 \alpha, 5 \alpha$-THP) are also known to be produced by astrocytes, which are capable of stimulating the release of GNRH both in vitro and in vivo (el-Etr et al. 1995, Sim et al. 2001). Given the findings that several BMPs share a neurotropic capacity for dopaminergic neurons with other members of the TGF- $\beta$ superfamily through glial cells (Jordan et al. 1997, Reiriz et al. 1999, Samanta et al. 2007), it is presumable that hypothalamic

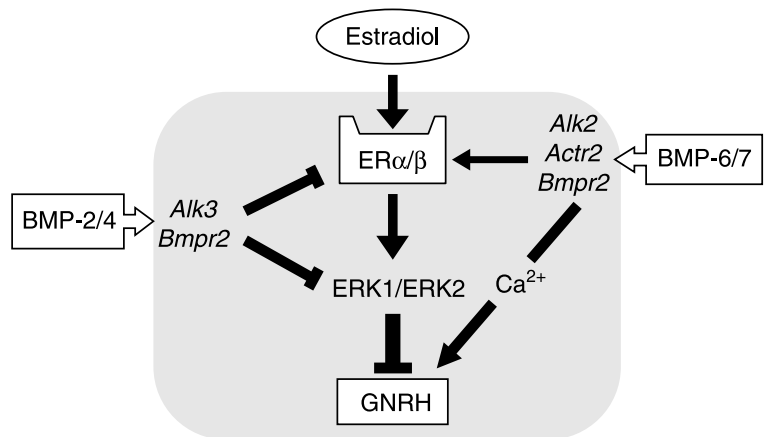

Figure $10 \mathrm{~A}$ possible mechanism by which BMPs and estrogen regulate GNRH production by GT1-7 cells. Estradiol suppresses GNRH production by inhibiting ERK1/ERK2 pathway via ER. In this feedback system between estradiol and GNRH production, BMP2 and BMP4 downregulate estrogen effects by attenuating estrogenERK signaling and ER $\alpha$ and ER $\beta$ expression. In contrast, BMP6 and BMP7 directly stimulate Gnrh transcription, GNRH production, and GNRH release via increased expression of $\alpha 1 \mathrm{E}$-subunit of R-type calcium channel, which is critical for GNRH secretion. A new interaction of BMPs and ER action may be involved in controlling hypothalamic GNRH production and secretion in an autocrine/ paracrine mechanism. 
GNRH production and/or secretion may also be indirectly regulated by BMP system in the neural network.

In addition, GT1-7 cells generate spontaneous action potentials, exhibit transient oscillations of the intracellular calcium concentration, and secrete $\mathrm{GnRH}$ in a pulsatile manner (Charles \& Hales 1995, Sun et al. 1998, Morales et al. 2005). The expression of the R-, L-, N-, and T-type calcium channels was demonstrated in GT1-7 cells, in which the R-type subunit plays a key role as a major current component for regulating calcium-dependent GNRH release compared with L-, N-, and T-type channels (Watanabe et al. 2004). Since BMP6 and BMP7 increased mRNA expression of $\alpha 1 \mathrm{E}-$ subunit of R-type calcium channel, which is a critical subunit for hypothalamic GNRH secretion, it seems likely that BMP6 and BMP7 directly stimulate GNRH release by GT1-7 cells. Further investigation would be necessary to clarify whether BMP6 and BMP7 physiologically stimulate calcium channel activity in GNRH neural cells in the future study.

Recent studies have shown that BMPs regulate the pituitary-gonadal endocrine axis. However, roles of BMPs in hypothalamic GNRH production have yet to be clarified. Understanding the neural mechanisms through which $\mathrm{E}_{2}$ regulates GNRH neurons is key for elucidating reproductive control of the HPO axis. We uncovered here the effects of BMPs on GNRH regulation controlled by estrogen in hypothalamic neuron cells. In particular, BMP2 and BMP4 downregulate estrogen effects on suppressing GNRH production by attenuating estrogen ERK signaling and by suppressing ER expression. On the contrary, BMP6 and BMP7 contribute to increase in GNRH secretion. Hence, a new interaction of BMPs and ER may be involved in controlling hypothalamic GNRH production and secretion in an autocrine/paracrine mechanism (Fig. 10). The BMP system may play a key role in regulating not only in the ovarian folliculogenesis by regulating gonadotropin sensitivity but also in modulating hypothalamic GNRH secretions leading to fine-tuning of gonadotropin secretion from the pituitary gonadotrope.

\section{Declaration of interest}

All authors have nothing to disclose.

\section{Funding}

This work was supported in part by Grants-in-Aid for Scientific Research, The Naito Foundation, Kanae Foundation for The Promotion of Medical Science, and Kanzawa Medical Research Foundation. M T was supported by the National Institute of Child Health and Human Development/National Institutes of Health through Grant R01 HD 037568 and U54 HD12303 as part of the Specialized Co-operative Centers Program in Reproduction and Infertility Research to M A L.

\section{Acknowledgements}

We thank Dr Pamela L Mellon for providing GT1-7 cells. We also thank Dr R Kelly Moore for helpful discussion and critical reading of the manuscript.

\section{References}

Avola R, Spina-Purrello V, Gallo F, Morale MC, Marletta N, Costa A, Tirolo C, Testa N, Reale S \& Marchetti B 2000 Immortalized hypothalamic luteinizing hormone-releasing hormone (LHRH) neurons induce a functional switch in the growth factor responsiveness of astroglia: involvement of basic fibroblast growth factor. International Journal of Developmental Neuroscience 18 743-763.

Bowe J, Li XF, Sugden D, Katzenellenbogen JA, Katzenellenbogen BS \& O'Byrne KT 2003 The effects of the phytoestrogen, coumestrol, on gonadotropin-releasing hormone (GnRH) mRNA expression in GT1-7 GnRH neurones. Journal of Neuroendocrinology 15 105-108.

Buchanan CD, Mahesh VB \& Brann DW 2000 Estrogen-astrocyte-luteinizing hormone-releasing hormone signaling: a role for transforming growth factor-beta(1). Biology of Reproduction 62 1710-1721.

Chappell PE, White RS \& Mellon PL 2003 Circadian gene expression regulates pulsatile gonadotropin-releasing hormone $(\mathrm{GnRH})$ secretory patterns in the hypothalamic GnRH-secreting GT1-7 cell line. Journal of Neuroscience 23 11202-11213.

Charles AC \& Hales TG 1995 Mechanisms of spontaneous calcium oscillations and action potentials in immortalized hypothalamic (GT1-7) neurons. Journal of Neurophysiology 73 56-64.

Dhandapani KM, Mahesh VB \& Brann DW 2003 Astrocytes and brain function: implications for reproduction. Experimental Biology and Medicine 228 253-260.

el-Etr M, Akwa Y, Fiddes RJ, Robel P \& Baulieu EE 1995 A progesterone metabolite stimulates the release of gonadotropin-releasing hormone from GT1-1 hypothalamic neurons via the gamma-aminobutyric acid type A receptor. PNAS 92 3769-3773.

Gaido KW, Leonard LS, Maness SC, Hall JM, McDonnell DP, Saville B \& Safe S 1999 Differential interaction of the methoxychlor metabolite 2,2-bis-( $p$-hydroxyphenyl)-1,1,1-trichloroethane with estrogen receptors alpha and beta. Endocrinology 140 5746-5753.

Galbiati M, Zanisi M, Messi E, Cavarretta I, Martini L \& Melcangi RC 1996 Transforming growth factor-beta and astrocytic conditioned medium influence luteinizing hormone-releasing hormone gene expression in the hypothalamic cell line GT1. Endocrinology 137 5605-5609.

Gallo V \& Russell JT 1995 Excitatory amino acid receptors in glia: different subtypes for distinct functions? Journal of Neuroscience Research 42 1-8.

Herbison AE 1998 Multimodal influence of estrogen upon gonadotropinreleasing hormone neurons. Endocrine Reviews 19 302-330.

Herbison AE \& Pape JR 2001 New evidence for estrogen receptors in gonadotropin-releasing hormone neurons. Frontiers in Neuroendocrinology 22 292-308.

Huang H-J, Wu JC, Su P, Zhirnov O \& Miller WL 2001 A novel role for bone morphogenetic proteins in the synthesis of follicle-stimulating hormone. Endocrinology 142 2275-2283.

Inagaki K, Otsuka F, Suzuki J, Kano Y, Takeda M, Miyoshi T, Otani H, Mimura Y, Ogura T \& Makino H 2006 Involvement of bone morphogenetic protein- 6 in differential regulation of aldosterone production by angiotensin II and potassium in human adrenocortical cells. Endocrinology 147 2681-2689.

Jordan J, Bottner M, Schluesener HJ, Unsicker K \& Krieglstein K 1997 Bone morphogenetic proteins: neurotrophic roles for midbrain dopaminergic neurons and implications of astroglial cells. European Journal of Neuroscience 9 1699-1709.

Kano Y, Otsuka F, Takeda M, Suzuki J, Inagaki K, Miyoshi T, Miyamoto M, Otani H, Ogura T \& Makino H 2005 Regulatory roles of bone morphogenetic proteins and glucocorticoids in catecholamine production by rat pheochromocytoma cells. Endocrinology 146 5332-5340.

Liposits Z, Merchenthaler I, Wetsel WC, Reid JJ, Mellon PL, Weiner RI \& Negro-Vilar A 1991 Morphological characterization of immortalized hypothalamic neurons synthesizing luteinizing hormone-releasing hormone. Endocrinology 129 1575-1583.

Ma YJ, Junier MP, Costa ME \& Ojeda SR 1992 Transforming growth factoralpha gene expression in the hypothalamus is developmentally regulated and linked to sexual maturation. Neuron 9 657-670. 
Ma YJ, Berg-von der Emde K, Rage F, Wetsel WC \& Ojeda SR 1997 Hypothalamic astrocytes respond to transforming growth factor-alpha with the secretion of neuroactive substances that stimulate the release of luteinizing hormone-releasing hormone. Endocrinology 138 19-25.

Malyala A, Kelly MJ \& Ronnekleiv OK 2005 Estrogen modulation of hypothalamic neurons: activation of multiple signaling pathways and gene expression changes. Steroids 70 397-406.

Melcangi RC, Ballabio M, Magnaghi V \& Celotti F 1995a Metabolism of steroids in pure cultures of neurons and glial cells: role of intracellular signalling. Journal of Steroid Biochemistry and Molecular Biology 53 331-336.

Melcangi RC, Galbiati M, Messi E, Piva F, Martini L \& Motta M 1995 b Type 1 astrocytes influence luteinizing hormone-releasing hormone release from the hypothalamic cell line GT1-1: is transforming growth factor-beta the principle involved? Endocrinology 136 679-686.

Miyoshi T, Otsuka F, Suzuki J, Takeda M, Inagaki K, Kano Y, Otani H, Mimura Y, Ogura T \& Makino H 2006 Mutual regulation of folliclestimulating hormone signaling and bone morphogenetic protein system in human granulosa cells. Biology of Reproduction 74 1073-1082.

Miyoshi T, Otsuka F, Otani H, Inagaki K, Goto J, Yamashita M, Ogura T, Iwasaki Y \& Makino H 2008 Involvement of bone morphogenetic protein4 in $\mathrm{GH}$ regulation by octreotide and bromocriptine in rat pituitary GH3 cells. Journal of Endocrinology 197 159-169.

Morales A, Diaz M, Guelmes P, Marin R \& Alonso R 2005 Rapid modulatory effect of estradiol on acetylcholine-induced $\mathrm{Ca}^{2+}$ signal is mediated through cyclic-GMP cascade in LHRH-releasing GT1-7 cells. European Journal of Neuroscience 22 2207-2215.

Navarro CE, Abdul Saeed S, Murdock C, Martinez-Fuentes AJ, Arora KK, Krsmanovic LZ \& Catt KJ 2003 Regulation of cyclic adenosine $3^{\prime}, 5^{\prime}$ monophosphate signaling and pulsatile neurosecretion by Gi-coupled plasma membrane estrogen receptors in immortalized gonadotropinreleasing hormone neurons. Molecular Endocrinology 17 1792-1804.

Nelson SB, Lawson MA, Kelley CG \& Mellon PL 2000 Neuron-specific expression of the rat gonadotropin-releasing hormone gene is conferred by interactions of a defined promoter element with the enhancer in GT1-7 cells. Molecular Endocrinology 14 1509-1522.

Nicol L, Faure MO, McNeilly JR, Fontaine J, Taragnat C \& McNeilly AS 2008 Bone morphogenetic protein-4 interacts with activin and GnRH to modulate gonadotrophin secretion in LbetaT2 gonadotrophs. Journal of Endocrinology 196 497-507.

Ojeda SR, Ma YJ, Lee BJ \& Prevot V 2000 Glia-to-neuron signaling and the neuroendocrine control of female puberty. Recent Progress in Hormone Research 55 197-223 (discussion 223-194).

Otani H, Otsuka F, Inagaki K, Takeda M, Miyoshi T, Suzuki J, Mukai T, Ogura T \& Makino H 2007 Antagonistic effects of bone morphogenetic protein- 4 and -7 on renal mesangial cell proliferation induced by aldosterone through MAPK activation. American Journal of Physiology. Renal Physiology 292 F1513-F1525.

Otsuka F \& Shimasaki S 2002a A negative feedback system between oocyte bone morphogenetic protein 15 and granulosa cell kit ligand: its role in regulating granulosa cell mitosis. PNAS 99 8060-8065.

Otsuka F \& Shimasaki S $2002 b$ A novel function of bone morphogenetic protein-15 in the pituitary: selective synthesis and secretion of FSH by gonadotropes. Endocrinology 143 4938-4941.

Otsuka F, Yao Z, Lee TH, Yamamoto S, Erickson GF \& Shimasaki S 2000 Bone morphogenetic protein-15: identification of target cells and biological functions. Journal of Biological Chemistry 275 39523-39528.

Otsuka F, Moore RK \& Shimasaki S 2001a Biological function and cellular mechanism of bone morphogenetic protein-6 in the ovary. Journal of Biological Chemistry 276 32889-32895.

Otsuka F, Yamamoto S, Erickson GF \& Shimasaki S $2001 b$ Bone morphogenetic protein-15 inhibits follicle-stimulating hormone (FSH) action by suppressing FSH receptor expression. Journal of Biological Chemistry 276 11387-11392.

Petersen SL, Ottem EN \& Carpenter CD 2003 Direct and indirect regulation of gonadotropin-releasing hormone neurons by estradiol. Biology of Reproduction 69 1771-1778.
Pietras RJ \& Szego CM 1999 Cell membrane estrogen receptors resurface. Nature Medicine $\mathbf{5} 1330$.

Pietras RJ, Levin ER \& Szego CM 2005 Estrogen receptors and cell signaling. Science 310 51-53 (author reply 51-53)

Reiriz J, Espejo M, Ventura F, Ambrosio S \& Alberch J 1999 Bone morphogenetic protein-2 promotes dissociated effects on the number and differentiation of cultured ventral mesencephalic dopaminergic neurons. Journal of Neurobiology 38 161-170.

Roy D, Angelini NL \& Belsham DD 1999 Estrogen directly respresses gonadotropin-releasing hormone $(\mathrm{GnRH})$ gene expression in estrogen receptor-alpha (ERalpha)- and ER beta-expressing GT1-7 GnRH neurons. Endocrinology 140 5045-5053.

Samanta J, Burke GM, McGuire T, Pisarek AJ, Mukhopadhyay A, Mishina Y \& Kessler JA 2007 BMPR1a signaling determines numbers of oligodendrocytes and calbindin-expressing interneurons in the cortex. Journal of Neuroscience 27 7397-7407.

Shimasaki S, Moore RK, Otsuka F \& Erickson GF 2004 The bone morphogenetic protein system in mammalian reproduction. Endocrine Reviews 25 72-101.

Sim JA, Skynner MJ \& Herbison AE 2001 Direct regulation of postnatal GnRH neurons by the progesterone derivative allopregnanolone in the mouse. Endocrinology 142 4448-4453.

Sun Y, Gore AC \& Roberts JL 1998 The role of calcium in the transcriptional and posttranscriptional regulation of the gonadotropin-releasing hormone gene in GT1-7 cells. Endocrinology 139 2685-2691.

Taguchi Y, Koslowski M \& Bodenner DL 2004 Binding of estrogen receptor with estrogen conjugated to bovine serum albumin (BSA). Nuclear Receptor 25.

Takahashi M, Otsuka F, Miyoshi T, Otani H, Goto J, Yamashita M, Ogura T, Makino H \& Doihara H 2008 Bone morphogenetic protein 6 (BMP6) and BMP7 inhibit estrogen-induced proliferation of breast cancer cells by suppressing p38 mitogen-activated protein kinase activation. Journal of Endocrinology 199 445-455.

Takeda M, Otsuka F, Suzuki J, Kishida M, Ogura T, Tamiya T \& Makino H 2003 Involvement of activin/BMP system in development of human pituitary gonadotropinomas and nonfunctioning adenomas. Biochemical and Biophysical Research Communications 306 812-818.

Takeda M, Otsuka F, Otani H, Inagaki K, Miyoshi T, Suzuki J, Mimura Y, Ogura T \& Makino H 2007 Effects of peroxisome proliferator-activated receptor activation on gonadotropin transcription and cell mitosis induced by bone morphogenetic proteins in mouse gonadotrope L $\beta$ T2 cells. Journal of Endocrinology 194 87-99.

Watanabe M, Sakuma Y \& Kato M 2004 High expression of the R-type voltage-gated $\mathrm{Ca}^{2+}$ channel and its involvement in $\mathrm{Ca}^{2+}$-dependent gonadotropin-releasing hormone release in GT1-7 cells. Endocrinology 145 2375-2383

Wetsel WC, Mellon PL, Weiner RI \& Negro-Vilar A 1991 Metabolism of pro-luteinizing hormone-releasing hormone in immortalized hypothalamic neurons. Endocrinology 129 1584-1595.

Whyte DB, Lawson MA, Belsham DD, Eraly SA, Bond CT, Adelman JP \& Mellon PL 1995 A neuron-specific enhancer targets expression of the gonadotropin-releasing hormone gene to hypothalamic neurosecretory neurons. Molecular Endocrinology 9 467-477.

Zwain IH, Arroyo A, Amato P \& Yen SS 2002 A role for hypothalamic astrocytes in dehydroepiandrosterone and estradiol regulation of gonadotropin-releasing hormone $(\mathrm{GnRH})$ release by $\mathrm{GnRH}$ neurons. Neuroendocrinology 75 375-383.

Received in final form 1 July 2009

Accepted 27 July 2009

Made available online as an Accepted

Preprint 27 July 2009 